\title{
Review \\ Intracranial Response Rate in Patients with Breast Cancer Brain Metastases after Systemic Therapy
}

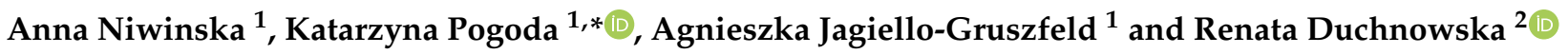 \\ 1 Department of Breast Cancer and Reconstructive Surgery, Maria Sklodowska-Curie National Research \\ Institute of Oncology, Roentgena 5 Str, 02-781 Warsaw, Poland; anna.niwinska@pib-nio.pl (A.N.); \\ agnieszka.jagiello-gruszfeld@pib-nio.pl (A.J.-G.) \\ 2 Department of Oncology, Military Institute of Medicine, Szaserów 128 Str, 04-141 Warsaw, Poland; \\ rduchnowska@wim.mil.pl \\ * Correspondence: katarzyna.pogoda@pib-nio.pl; Tel.: +48-22-5462-435
}

check for updates

Citation: Niwinska, A.; Pogoda, K.; Jagiello-Gruszfeld, A.; Duchnowska, R. Intracranial Response Rate in Patients with Breast Cancer Brain Metastases after Systemic Therapy. Cancers 2022, 14, 965. https:// doi.org/10.3390/cancers14040965

Academic Editor: Cynthia Ma

Received: 30 December 2021

Accepted: 10 February 2022

Published: 15 February 2022

Publisher's Note: MDPI stays neutral with regard to jurisdictional claims in published maps and institutional affiliations.

Copyright: (C) 2022 by the authors. Licensee MDPI, Basel, Switzerland. This article is an open access article distributed under the terms and conditions of the Creative Commons Attribution (CC BY) license (https:// creativecommons.org/licenses/by/ $4.0 /)$.
Simple Summary: For many years, patients with breast cancer and brain metastases were excluded from participation in clinical trials. It was believed that anticancer drugs could not cross the bloodbrain barrier. However, recent evidence strongly suggests that some drugs can act against brain metastases, with the greatest intracranial response rate reported in the case of capecitabine, neratinib plus capecitabine, trastuzumab deruxtecan and tucatinib plus trastuzumab and capecitabine. In this article, we discuss the achievements in systemic therapy of breast cancer patients with brain metastases. We stress on the newest clinical trial results which indicate tremendous progress in HER2-positive breast cancer. On the other hand, in patients with triple-negative breast cancer or hormone-receptor-positive brain metastases, much fewer compounds were discovered. Based on the presented results, patients with active brain metastases should be routinely included in clinical trials with novel agents.

Abstract: Brain metastases are detected in 5\% of patients with breast cancer at diagnosis. The rate of brain metastases is higher in HER2-positive and triple-negative breast cancer patients (TNBC). In patients with metastatic breast cancer, the risk of brain metastases is much higher, with up to $50 \%$ of the patients having two aggressive biological breast cancer subtypes. The prognosis for such patients is poor. Until recently, little was known about the response to systemic therapy in brain metastases. The number of trials dedicated to breast cancer with brain metastases was scarce. Our review summarizes the current knowledge on this topic including very significant results of clinical trials which have been presented very recently. We focus on the intracranial response rate of modern drugs, including new antibody-drug conjugates, HER2- targeted tyrosine kinase inhibitors and other targeted therapies. We highlight the most effective and promising drugs. On the other hand, we also suggest that further efforts are needed to improve the prognosis, especially patients with TNBC and brain metastases. The information contained in this article can help oncologists make treatment-related decisions.

Keywords: brain metastases; breast cancer; CNS; intracranial response; targeted therapy

\section{Introduction}

Breast cancer has come to be recognized as the second most common solid tumor that metastasizes to the central nervous system (CNS) [1]. This seems to be the consequence of the increased detection of metastatic disease through advanced imaging techniques and thus improved survival rates of patients with metastatic breast cancer.

At initial diagnosis, brain metastases are detected in $5 \%$ of patients with breast cancer. The incidence of brain metastases varies amounting to $1 \%$ in luminal A, $2 \%$ in luminal B, $4 \%$ in human epidermal growth factor receptor 2 (HER2)-positive and $6 \%$ in triple-negative 
(TNBC) breast cancer. In patients with metastatic breast cancer, the risk of brain metastases is much higher. In HER2-positive breast cancer and TNBC, the rates of brain metastases are $11-49 \%$ and $26-46 \%$, respectively, while in patients with metastatic luminal A and B cancer, the risk of brain metastases are $8-15 \%$ and $11 \%$, respectively [2-8].

Current therapeutic options for patients with breast cancer brain metastases include surgical resection, stereotactic radiosurgery (SRS), whole-brain radiation therapy (WBRT), and systemic therapy (i.e., chemotherapy and targeted therapy) [9]. Until recently, the efficacy of the systemic therapy in patients with brain metastases had not been studied in clinical trials because it was generally believed that the blood-brain barrier (BBB), formed by a tight junction of endothelial cells, a thick basement membrane of pericytes, and astrocytic end-foot processes [10], was not permeable for almost all drugs. Patients with brain metastases were, consequently, excluded from randomized clinical trials assessing the efficacy of new systemic agents. Among the 1474 clinical trials concerned with metastatic breast cancer carried out, only 16 (1\%) concerned CNS metastases from breast cancer [11]. Meanwhile, basic research has shown that the blood-tumor barrier (BTB) is more permeable to some agents than the BBB, especially in the case of macrometastases with neovascularization [12-14]. Moreover, retrospective and prospective observational clinical studies seem to indicate the efficacy of some systemic drugs in patients with multiple and single brain metastases and even in solitary brain metastases without dissemination to other organs [15-17]. There are suggestions that BBB can be disrupted by neovascularization during progression and become BTB. On the other hand, micrometastases and meningeal carcinomatosis have less abnormal vessels which prevent access to systemic therapies [9]. This observation could force other strategy to deliver effective solution. Additionally, there can be differences in brain metastases location in breast cancer patients compared to other primary tumors. Brain metastases from breast cancer were more frequently located in cerebellum in retrospective study which could have occurred due to increased cortico-junctional surface and better perfusion $[18,19]$.

Until recently, relatively little was known of the intracranial objective response rate to systemic therapy. However, research in this field is given ever more attention. According to ClinicalTrial.gov, more than 100 trials on breast cancer brain metastases are now in progress, including studies focusing on new agents (cyclin-dependent kinase (CDK) inhibitors, poly (ADP-ribose) polymerase (PARP) inhibitors, phosphoinositide 3-kinase (PI3K) inhibitors, new generation tyrosine kinase inhibitors (TKIs), anti-HER2 conjugates, immune drugs) with the evaluation of the objective intracranial response rate as one of the study endpoints [9].

\section{Aim}

The aim of this overview was to analyze the objective intracranial response rate (iORR) and the clinical benefit rate (iCBR; complete response $(C R)+$ partial response $(P R)+$ stable disease (SD)) of known and new systemic agents used in breast cancer patients with brain metastases including the most recent clinical trial results.

\section{HER2-Positive Breast Cancer}

The group of patients with HER2-positive breast cancer and brain metastases is best represented with regard to the number of studies assessing the intracranial response rate after cytotoxic drugs and targeted therapy. A meta-analysis of 97 studies by Erickson et al. showed that HER2-targeted therapy was associated with improved overall survival (OS) (hazard ratio (HR) 0.47; 95\% confidence interval (CI) 0.39-0.56) in patients with HER2-positive breast cancer and intracranial metastases compared to the nontargeted therapy group. The iORR was $22 \%$ (95\% CI, 14-30\%), intracranial disease control rate (iDCR) was 62\% (95\% CI, 55-69\%), and intracranial complete response rate was (iCRR) $0 \%$ (95\% CI, 0-0.01\%), with grade $\geq 3$ adverse event rate of $26 \%$ (95\% CI, 11-45\%). However, anti-HER2 therapy did not have a significant effect on the progression-free survival (PFS) (HR 0.52; 95\% CI, 0.27-1.02) [20]. 


\subsection{Monoclonal Antibodies}

Trastuzumab has been proved to be a monoclonal antibody that is very effective in controlling extracranial disease and prolonging the survival of patients with disseminated extracranial and intracranial disease [15], however its permeability through the BBB is limited [3]. Biodistribution of trastuzumab into the brain is a little better in patients after WBRT or in those with leptomeningeal metastases but it seems that the efficacy of this monoclonal antibody in breast cancer patients is rather the result of extracranial disease control [4].

Pertuzumab is a humanized monoclonal antibody preventing HER2/HER3 dimerization and resulting in a double blockage when associated with trastuzumab. In the CLEOPATRA randomized trial with trastuzumab plus docetaxel vs. trastuzumab plus docetaxel plus pertuzumab, a major impact on the OS in the pertuzumab arm was shown (56.5 vs. 40 months), but the trial did not include patients with brain metastases [21]. During the observation, the rate of newly detected CNS metastases in both arms was comparable (13.7\% and $12.6 \%, p=$ not significant (NS)) but the onset of CNS metastases was delayed in the pertuzumab group (15 vs. 11.9 months, $p=0.005)$ probably due to better control of extracranial disease by pertuzumab [22]. In the phase II single arm PATRICIA trial, 40 patients with progressing brain metastases after previous radiation therapy received pertuzumab (a loading of dose $840 \mathrm{mg}$, then $420 \mathrm{mg}$ every 3 weeks) plus a high dose of trastuzumab (6 mg/kg weekly) [23-25]. The iORR was $11 \%$ and the $6-$ month iCBR was 51\%.

\subsection{Antibody-Drug Conjugates}

Trastusumab emtansine (T-DM1) is a conjugate of trastuzumab and emtansine. Retrospective studies confirm the intracranial efficacy of T-DM1 with an iORR of $24-44 \%$ and a CBR of 55-70\% [24,26-30]. The analysis of 10 patients revealed a 30\% iORR rate during a period of 5 months [26]. In another group of 39 patients, the rate of iORR was $44 \%$ and the rate of $\mathrm{iCBR}$ was 59\% [27]. In an Italian retrospective study, the iORR in 53 patients with brain metastases was $24.5 \%$ and the CBR was observed in $55 \%$ of the patients for a period of 7 months [28]. The EMILIA randomized phase III trial compared T-DM1 vs. lapatinib plus capecitabine in 991 HER2-positive breast cancer patients previously treated with trastuzumab [31,32]. T-DM1 was shown to prolong the OS as compared with lapatinib plus capecitabine. In a retrospective, exploratory analysis of 90 patients with brain metastases included in the EMILIA trial [33], it was revealed that patients with asymptomatic brain metastases treated with T-DM1 lived longer than those treated with lapatinib plus capecitabine (26.8 months vs. 12.9 months, respectively, $\mathrm{HR}=0.38 ; p=0.008$ ), but the time to progression in the brain did not differ in the two arms (5.9 vs. 5.7 months, respectively). The KAMILLA trial was a single-arm phase III b study evaluating the safety of T-DM1 in HER2-positive locally advanced or metastatic breast cancer previously treated with HER2-targeted therapy and chemotherapy [29]. Among the 2220 patients enrolled into the study, 398 were patients with stable or occult brain metastases. The intracranial response rate was assessed in 126 patients [30]. The PR according to RECIST 1.1 (Response Criteria in Solid Tumors 1.1) criteria was achieved in $42.9 \%$ of patients and the CBR in $67 \%$. The median PFS and OS were 5.5 and 18.9 months, respectively.

Trastuzumab-Deruxtecan (T-DXd) is an anti-HER2 monoclonal antibody linked to the topoisomerase inhibitor via a cleavable linker. T-DXd binds HER2 on tumor cells, then is internalized. After that the linker is cleaved within the cell by lysosomal enzymes and released DXd inhibits topoisomerase I-DNA complexes. This process leads to tumor cell apoptosis [34]. T-DXd was approved for use in the United States and the European Union in unresectable or metastatic HER2-positive breast cancer patients who have received two or more prior anti-HER2 based regimens in the metastatic setting based on the DESTINYBreast 01 trial [35]. In that trial, 261 patients received T-DXd and 263 received T-DM1. A subgroup analysis of 24 patients with brain metastases revealed an iORR of 58.3\% [36]. During the San Antonio Breast Cancer Symposium 2021, the results of a subanalysis of the phase III study DESTINY-Breast 03 [37] was presented. T-DXd was compared with 
T-DM1 in 524 unresected or metastatic breast cancer previously treated with trastuzumab and taxanes. In that trial, patients with clinically stable, treated brain metastases could be administered the treatment at least 2 weeks after WBRT. In total, 62 patients with brain metastases in the T-DXd arm and 52 patients in the T-DM1 arm were included and in 43 and 39 of them, respectively, brain metastases were detected at baseline. In all patients with brain metastases computed tomography or magnetic resonance was performed at baseline and monitored throughout the study. The median follow-up of that brain metastases group was 15.9 months. The 12-month PFS rate in patients treated with T-DXd was $75.8 \%$ and in those treated with T-DM1 was $34 \%, \mathrm{HR}=0.28(p<0.001)$. In patients with brain metastases at baseline, the median PFS after T-DXd and T-DM1 was 15 months and 3 months, respectively. The 12 -months PFS rate was $72 \%$ and $21 \%$, respectively $(\mathrm{HR}=0.25)$. The iORR assessed with RECIST 1.1 criteria in the group with T-DXd was $63.9 \%$ (CR 27.8\%; PR 36.1\%) and in the group with T-DM1 it was 33.4\% (CR 2.8\%, PR 30.6\%). The iCR in the T-DXd and the T-DM1 group were $27.8 \%$ and $2.8 \%$, respectively. The PR in the groups was $36.1 \%$ and $30.6 \%$, respectively. The results confirm that the T-DXd treatment is associated with a substantial intrathecal response and reduction in CNS parenchymal disease. T-DXd demonstrated a manageable and tolerable safety profile [34]. The second SABCS 2021 abstract described DEBBRAH phase II trial [38]. Here, 39 patients with HER2-positive or HER2-low expression breast cancer and brain or leptomeningeal metastases were treated with T-DXd. In total, 17 patients had luminal B biological subtype. The iORR was achieved in $44 \%$ and $\mathrm{iCRB}$ in $55 \%$ of patients.

\subsection{HER2- Targeted Tyrosine Kinase Inhibitors (TKIs)}

Lapatinib is an oral, small dual TKI that binds HER2 and HER1 receptors. In a phase II study of lapatinib as a single agent used in heavily pretreated patients, the volumetric CNS iORR was 6\% [39]. In another phase II study, lapatinib plus capecitabine was evaluated in 50 patients and an iORR of $20 \%$ was shown [39]. In the study by Cetin [40], 85 out of 203 patients with brain metastases were treated with lapatinib plus capecitabine and the iORR of $27 \%$ of them was achieved. Sutherland treated 34 patients with brain metastases with the same regimen and in $21 \%$ of them an iORR was noted [41]. In a systematic review and pooled analysis, the efficacy of 799 patients treated with lapatinib plus capecitabine was analyzed [42]. The iORR was 29.2\%, the PFS was 4.1 months and the OS was 12.2 months. In the LANDSCAPE trial, the intracranial response rate after lapatinib plus capecytabine in previously untreated patients with brain metastases was assessed. The volumetric iORR was $66 \%$, suggesting that such a combined therapy, instead of radiotherapy, could be a feasible first-line treatment in HER2-positive breast cancer brain metastases [43]. Lapatinib was investigated in association with temozolomide (TMZ) in heavily pretreated patients with HER2-positive breast cancer and brain metastases, in phase I LAPTEM trial. Stabilization of the disease was achieved in $66.7 \%$ out of the 15 treated patients with a median PFS of 2.6 months and a median OS of 10.9 months [44]. A phase II randomized trial compared the iORR in patients treated with SRS and lapatinib plus capecitabine and patients treated with SRS and lapatinib plus topotecan. Only 22 out of the 110 planned patients were included in the study due to high toxicity in the experimental arm. The iORR defined as a $>=50 \%$ volumetric reduction was $38 \%$ and $0 \%$, respectively [45].

Neratinib is an oral, irreversible pan-inhibitor of HER2-TKI family that binds HER1, HER2 and HER4 receptors. In the Translational Breast Cancer Research Consortium (TBCRC) 022 phase II trial, the efficacy of neratinib was assessed in patients with pretreated, progressing brain metastases. Four different groups of patients were included: with neratinib monotherapy (cohort 1), with neratinib after surgical resection (cohort 2), with neratinib plus capecitabine in patients without (cohort 3A) or with previous lapatinib therapy (cohort 3B), and with neratinib plus ado-trastuzumab emtansine (cohort 4). In 40 patients treated with neratinib monotherapy, 78\% were after WBRT. In that group, the iORR rate was only $8 \%$. In patients treated with neratinib plus capecitabine without previous treatment with lapatinib the iORR was 49\% (95\% CI: 32-66) and in patients treated 
previously with lapatinib iORR was 33\% (95\% CI: 10-65). Time to progression was 5.5 and 3 months and OS was 13 and 15 months, respectively [46]. In the phase III NALA randomized trial, neratinib plus capecitabine was compared to lapatinib plus capecitabine in heavily pretreated patients ( 307 vs. 314 , respectively). Patients with symptomatic brain metastases were excluded from the trial but patients with occult brain metastases were included. One-year PFS rate after neratinib plus capecitabine vs. lapatinib plus capecitabine was $37.8 \%$ and $14.8 \%$, respectively. OS did not differ significantly in both groups. The time to intervention for brain progression was longer in neratinib group (overall cumulative incidence $22.8 \%$ in neratinib group and $29.2 \%$ in lapatinib group, $p=0.04$ ) [47]. Grade 3 diarrhea in the group with neratinib and lapatinib was observed in $24 \%$ and $12 \%$, respectively. Based on these results in 2019, NCCN decided to indicate both capecitabine plus lapatinib and capecitabine plus neratinib as therapeutic options in HER2-positive breast cancer patients with brain metastases. In another phase III NEfERT trial, neratinib plus paclitaxel was compared with trastuzumab plus paclitaxel in patients with advanced breast cancer. In the neratinib arm longer time to new brain metastases and lower rate to brain metastases' progression ( $8.3 \%$ vs. $17.3 \%$, respectively, $p=0.045$ ) was observed [48].

Afatinib is an oral, irreversible HER1 and HER2 TKI. In the LUX-Breast 3 phase II study, 121 HER2-positive breast cancer patients with progressive or recurrent brain metastases after trastuzumab and/or lapatinib treatment, were randomized into one of 3 cohorts: with SRS and afatinib alone, with SRS and afatinib plus vinorelbine or with SRS and treatment of the physician's choice [49]. The iCBR defined as no progression in CNS invasion after 3 months were $30 \%, 34 \%$ and $41.9 \%$, respectively, and the toxicity profiles were worse in the afatinib-containing regimens.

Tucatinib is an oral, reversible HER2 and HER1 TKI whose active metabolites can cross the BBB. In a phase I study, tucatinib plus capecitabine and trastuzumab were tested in 12 patients with brain metastases. In (5) $42 \%$ of patients, the iORR was assessed with RECIST 1.1 [50]. In a phase II randomized HER2CLIMB study, tucatinib plus capecitabine and trastuzumab was compared with placebo plus capecitabine and trastuzumab in patients previously treated with trastuzumab, pertuzumab, and T-DM1. In this trial, 612 patients with stable brain metastases were included [51]. In the tucatinib arm, improved PFS and OS values were observed. For patients with brain metastases, the 1-year PFS in the tucatinib-combination group was $29.4 \%$, while in the placebo-combination group it was $0 \%, p<0.001$ [49]. The updated analysis of 291 patients with brain metastases participating in a HER2CLIMB study [52] revealed that the risk of intracranial progression or death was reduced by $61 \%$ in the tucatinib arm. The median PFS in the brain was 9.9 months in the tucatinib arm vs. 4.2 months in the control arm. The iORR in the tucatinib arm and the control arm was $47.3 \%$ and $20 \%$, respectively $(p=0.03)$. The risk of death was reduced by $40 \%$ in the tucatinib arm. The median OS was 21.6 months and 12.5 months in favor of tucatinib. The authors concluded that the addition of tucatinib to trastuzumab and capecitabine doubled the iORR, reduced the risk of intracranial progression or death by two thirds, and reduced the risk of death by nearly a half. That regimen was the first to demonstrate an improved anticancer activity in the brain of patients with HER2-positive breast cancer in a randomized trial. The side effects after tucatinib (rash and diarrhea) were reduced compared with neratinib and lapatinib. Tucatinib, in combination with trastuzumab and capecitabine, has received the US Food and Drug Administration (FDA) and the European Medicines Agency (EMA) approval to be administered to women, with previously treated advanced HER2-positive breast cancer, with or without brain metastases.

Pyrotinib is an oral, irreversible TKI targeting HER1, HER2 and HER4. In the phase III randomized PHOEBE trial [53], 266 patients with HER2-positive metastatic breast cancer previously treated with trastuzumab, taxanes and/or anthracyclines were allocated to a pyrotinib plus capecitabine or a lapatinib plus capecitabine group. The median PFS in the pyrotinib and the lapatinib group was 12.5 and 6.8 months, respectively ( $\mathrm{HR}=0.48$, $p<0.0001)$. The median OS in the pyrotinib group was not reached and in the lapatinib group was 26.9 months $(\mathrm{HR}=0.69, p=0.02)$. Based on this trial, in 2020, China granted 
full approval of pyrotinib in combination with capecitabine as a second-line standard-ofcare treatment for HER2-positive metastatic breast cancer. In the PHOEBE trial, only $11 \%$ of patients presented brain metastases. In contrast, the PERMEATE study [54] assessed 78 patients with brain metastases who were divided into two cohorts: a cohort with no prior CNS radiotherapy (A) and a cohort with patients after radiotherapy (B). Both groups were treated with pyrotinib plus capecitabine. The intracranial ORR in cohorts A and B was $75 \%$ and $42 \%$, respectively. The CNS PFS in the groups was 11.3 (A) and 5.6 (B) months. This study confirmed the CNS activity of pyrotinib.

Epertinib is a reversible inhibitor of HER1, HER2, HER3 and HER4. In a I/II phase trial, 45 patients with breast cancer, including 5 patients with brain metastases, were assigned to one of 3 groups: with epertinib plus trastuzumab ( $\operatorname{arm~A),~with~trastuzumab~}$ plus vinorelbine (arm B), and with trastuzumab plus capecitabine (arm C). The PR in brain metastases was achieved by one of 2 patients in arm C and SD ( $\geq 6$ months) was seen in 2 of 3 patients with brain metastases in arm A [55].

\subsection{Other Targeted Therapy}

Cabozantinib is a small, multiple TKI that inhibits mesenchymal-epithelial transition factor (MET) and vascular endothelial growth factor (VEGF). In contrast to other tumors such as non-small cell lung cancer and renal cell carcinoma, the efficacy of cabozantinib in heavily pretreated breast cancer patients with brain metastases is modest (iORR per RECIST 5.6\%) [56].

Bevacizumab, a humanized anti-VEGF monoclonal antibody normalizes peritumoral vessels and enhances drug delivery to brain tumors. It was tested in two studies in patients with brain metastases in combination with other cytotoxic agents. In one study, bevacizumab, carboplatin and trastuzumab (in HER2-positive breast cancer patients) were assessed in 39 patients with progressive brain metastases. The iORR by composite criteria and RECIST was 63\% [57]. In the second study [58], patients with WBRT-refractory brain metastases received bevacizumab followed by etoposide and cisplatin. The iORR according to the volumetric criteria was $77 \%$ and by RECIST- $54.3 \%$.

\section{Luminal Breast Cancer}

In estrogen receptor (ER)-positive metastatic breast cancer and brain metastases, some responses to tamoxifen [59], aromatase inhibitors [60] and fulvestrant [61] were reported in case-series studies.

Everolimus was investigated in combination with vinorelbine and trastuzumab in a study of 32 patients with progressive HER2-positive brain metastases, but the intracranial response rate was only $4 \%$ [62].

Abemaciclib is a selective CDK 4/6 inhibitor used in patients with hormone receptor (HR) positive HER2-negative metastatic breast cancer along with an endocrine therapy. Abemaciclib has a higher BBB penetration compared with other CDK4/6 inhibitors. The efficacy of drug in patients with brain metastases was assessed in a nonrandomized phase II study. In total, 58 HR-positive HER2-negative breast cancer patients with and $27 \mathrm{HR}-$ positive HER2-positive patients with brain metastases were treated with abemaciclib. The iORR was $5.2 \%$ and $0 \%$, respectively. The iCBR was $24 \%$ and $11 \%$. The median OS was 12.5 and 10 months, respectively. The study failed to document the efficacy of abemaciclib in the groups of heavily pretreated patients with brain metastases [63].

\section{Triple-Negative Breast Cancer}

PARP inhibitors: iniparib, olaparib, talazoparib, and veliparib were evaluated in metastatic TNBC. The phase II TBCRC 018 trial, including 34 patients treated with iniparib plus irinotecan, showed modest benefit of a 12\% iORR. The median PFS was 2.1 months and the median OS was 7.8 months [64]. In the phase III EMBRACA trial assessing patients with BRCAmutated advanced HER2-negative breast cancer, $15 \%$ of patients in the talazoparib arm had 
brain metastases at baseline [65]. In that subgroup, the PFS was better than in patients without CNS metastases, but the assessment of the intracranial response was not performed.

Ang1005 is a novel taxane agent, it consists of 3 paclitaxel molecules covalently linked to Angiopep-2 which help to cross the BBB. In a Phase II study, ANG 1005 was tested in 72 breast cancer patients with CNS metastases. The iORR was $15 \%$ and the iCBR was reported in $77 \%$ of patients [66].

Etirinotecan pegol is a long-lasting topoisomerase- 1 inhibitor. The phase III ATTAIN trial investigated etirinotecan pegol compared to the standard care in 178 patients with TNBC with stable brain metastases [67]. The patients had been treated with anthracycline, taxane and capecitabine previously. There was no difference in the OS between the two arms (7.8 and 7.5 months) as well as in PFS brain metastases (3.9 and 3.3 months).

Eribulin mesylate was evaluated in a prospective study of 118 heavily pretreated breast cancer patients. The iORR was reported in 16\% (12) of patients with brain metastases, with a PFS of 5.2 months [68].

Sacituzumab govitecan (SG) is a conjugate of an antibody and active metabolite of irinotecan. In a phase III ASCENT study, 529 patients with TNBC received SG or treatment of the physician' choice (TPC). 61(12\%) of patients had stable brain metastases. In that group, the PFS in SG and TPC was 2.8 and 1.6 months, the median OS was 6.8 and 7.5 months. The iORR was $3 \%$ and $0 \%$ and the $\mathrm{iCBR}$ was $9.4 \%$ and $3.4 \%$, respectively [69].

Immune therapy was evaluated in TNBC randomized clinical trials but not exclusively in patients with brain metastases. In the phase III Impassion-130 trial, 902 patients with metastatic TNBC were randomized to atezolizumab (an antibody that targets the programmed death (PD) ligand 1) with nab-paclitaxel or placebo with nab-paclitaxel. Only 7\% of patients in each arm had brain metastases, but, unlike in the whole group, no significant benefit from atezolizumab was observed in patients with brain metastases [70]. Based on TriNetX real-world and in-house database [71], 3449 TNBC patients treated with immune checkpoint inhibitors and 3461 patients nontreated with these agents were compared with regard to the OS. The median OS in each group was 23.9 vs. 11.6 months, respectively (HR $=0.87$ ). However, there is lack of evidence for the effectiveness of immune checkpoint inhibitors for treating brain metastases from TNBC, since approval for their use in this context was obtained relatively recently [68]. The immune-oncology therapy using atezolizumab (NCT03483012), nivolumab (NCT03807765), and pembrolizumab (NCT03449238) with SRS are under investigation. The first results from nivolumab trial showed that immune therapy in combination with SRS in 12 patients was safe and median intracranial control was 6.2 months [72]. The trials assessing the combined strategies of immune therapy with vaccine are ongoing (e.g., NCT04348747).

The results of clinical trials with breast cancer patients and brain metastases are summarized in Table 1.

Table 1. Intracranial response rate based on the results of available clinical trials including patients with breast cancer and brain metastases.

\begin{tabular}{|c|c|c|c|c|c|}
\hline Main Agent & Type of Study & $\begin{array}{c}\text { Number of } \\
\text { Patients with } \\
\text { Brain Metastases }\end{array}$ & $\begin{array}{l}\text { Scheme of } \\
\text { Treatment }\end{array}$ & $\begin{array}{c}\text { Intracranial } \\
\text { Response Rate * }\end{array}$ & $\begin{array}{c}\text { Median } \\
\text { PFS/OS } \\
\text { (Months) }\end{array}$ \\
\hline & \multicolumn{5}{|c|}{ HER2-positive breast cancer brain metastases } \\
\hline Pertuzumab & $\begin{array}{l}\text { PATRICIA phase II trial } \\
\text { [23] }\end{array}$ & 39 & $\begin{array}{l}\text { Pertuzumab + high } \\
\text { dose trastuzumab }\end{array}$ & $\begin{array}{c}\text { iORR } 11 \% \\
\text { iCBR } 68 \% \\
4 \text { mo. } \\
\text { iCBR } 51 \% 6 \text { mo. }\end{array}$ & - \\
\hline
\end{tabular}


Table 1. Cont.

\begin{tabular}{|c|c|c|c|c|c|}
\hline Main Agent & Type of Study & $\begin{array}{c}\text { Number of } \\
\text { Patients with } \\
\text { Brain Metastases }\end{array}$ & $\begin{array}{l}\text { Scheme of } \\
\text { Treatment }\end{array}$ & $\begin{array}{c}\text { Intracranial } \\
\text { Response Rate * }\end{array}$ & $\begin{array}{c}\text { Median } \\
\text { PFS/OS } \\
\text { (Months) }\end{array}$ \\
\hline \multirow{5}{*}{$\begin{array}{l}\text { Trastuzumab- } \\
\text { emtansine } \\
\text { (T-DM1) }\end{array}$} & $\begin{array}{l}\text { Bartsch [26] } \\
\text { retrospective }\end{array}$ & 10 & T-DM1 & $\begin{array}{l}\text { iORR 30\% } \\
\text { iCBR 50\% }\end{array}$ & PFS 5 \\
\hline & $\begin{array}{l}\text { Jacot [27] } \\
\text { retrospective }\end{array}$ & 39 & T-DM1 & $\begin{array}{l}\text { iORR } 44 \% \\
\text { iORR } 59 \%\end{array}$ & PFS 6 \\
\hline & $\begin{array}{l}\text { Fabi } 2018 \text { [28] } \\
\text { retrospective }\end{array}$ & 70 & T-DM1 & iORR $24.5 \%$ & $\begin{array}{l}\text { PFS } 7 \\
\text { OS } 14\end{array}$ \\
\hline & $\begin{array}{l}\text { KAMILLA phase IIIlb } \\
\text { trial [30] }\end{array}$ & $398 / 126$ & T-DM1 & $\begin{array}{l}\text { iORR } 21.4 \% \\
\text { iCBR } 43 \%\end{array}$ & $\begin{array}{l}\text { PFS } 5.5 \\
\text { OS } 18.9\end{array}$ \\
\hline & $\begin{array}{c}\text { DESTINY-Breast } 03 \text { [37] } \\
\text { phase III trial }\end{array}$ & 39 & T-DM1 & $\begin{array}{l}\text { iORR 33.4\% } \\
\text { iCR 2.8\% } \\
\text { iPR 30.6\% }\end{array}$ & PFS 3 \\
\hline \multirow{3}{*}{$\begin{array}{l}\text { Trastuzumab } \\
\text { deruxtecan } \\
\text { (T-DXd) }\end{array}$} & $\begin{array}{c}\text { DESTINY-Breast } 03 \text { [37] } \\
\text { phase III trial }\end{array}$ & 43 & T-DXd & $\begin{array}{l}\text { iORR 63.9\% } \\
\text { iCR 27.8\% } \\
\text { iPR 36.1\% }\end{array}$ & PFS 15 \\
\hline & $\begin{array}{l}\text { DESTINY-Breast } 01 \\
\quad \text { (Jerusalem [36] }\end{array}$ & 24 & T-DXd & $\begin{array}{l}\text { iORR 58.3\% } \\
\text { iCR } 4.2 \% \\
\text { iPR } 54.2 \% \\
\text { iSD } 33.3 \%\end{array}$ & PFS 18 \\
\hline & $\begin{array}{c}\text { DEBBRAH phase II trial } \\
{[38]}\end{array}$ & $\begin{array}{l}39 \text { HER2+ or } \\
\text { HER2-low }\end{array}$ & T-DXd & $\begin{array}{l}\text { iORR } 44 \% \\
\text { iCBR } 55 \%\end{array}$ & - \\
\hline \multirow{8}{*}{ Lapatinib } & $\begin{array}{c}\text { Lin } 2009 \text { phase II trial } \\
\text { [39] }\end{array}$ & 242 & Lapatinib alone & $\begin{array}{c}\text { iORR 6\% } \\
\text { Volumetric } \\
\text { reduction >= } \\
20-21 \%\end{array}$ & $\begin{array}{l}\text { PFS } 2.4 \\
\text { OS } 6.4\end{array}$ \\
\hline & $\begin{array}{c}\text { Lin } 2009 \text { phase II trial } \\
\text { [39] }\end{array}$ & 50 & $\begin{array}{l}\text { Lapatinib plus } \\
\text { capecitabine }\end{array}$ & iORR 20\% & - \\
\hline & $\begin{array}{l}\text { Cetin [40] retrospective } \\
\text { study }\end{array}$ & $203 / 85$ & $\begin{array}{l}\text { Lapatinib plus } \\
\text { capecitabine }\end{array}$ & $\begin{array}{l}\text { iORR 27\% } \\
\text { iCR } 2.4 \% \\
\text { iPR } 24.7 \% \\
\end{array}$ & $\begin{array}{l}\text { PFS } 7 \\
\text { OS } 13\end{array}$ \\
\hline & $\begin{array}{l}\text { Sutherland } 2010 \text { [41] } \\
\text { prospective study }\end{array}$ & $356 / 34$ & $\begin{array}{l}\text { Lapatinib plus } \\
\text { capecitabine }\end{array}$ & iORR 21\% & PFS 4.5 \\
\hline & $\begin{array}{l}\text { Petrelli } 2017 \text { [42] pooled } \\
\text { analysis }\end{array}$ & 799 & $\begin{array}{l}\text { Lapatinib plus } \\
\text { capecitabine }\end{array}$ & iORR $29.2 \%$ & $\begin{array}{l}\text { PFS } 4.1 \\
\text { OS } 12.2\end{array}$ \\
\hline & $\begin{array}{c}\text { Lin } 2011 \text { [45] phase II } \\
\text { trial }\end{array}$ & $\begin{array}{c}13 \\
9\end{array}$ & $\begin{array}{l}\text { Lapatinib plus } \\
\text { capecitabine } \\
\text { Lapatinib }+ \\
\text { topotecan }\end{array}$ & $\begin{array}{l}\text { iORR } 38 \% \\
\text { iCBR } 84 \% \\
\text { iORR } 0 \%\end{array}$ & - \\
\hline & $\begin{array}{l}\text { LANDSCAPE phase II } \\
\text { trial [43] }\end{array}$ & 45 before WBRT & $\begin{array}{l}\text { Lapatinib plus } \\
\text { capecitabine }\end{array}$ & iORR 65.9\% & - \\
\hline & $\begin{array}{l}\text { LAPTEM phase I trial } \\
\text { [44] }\end{array}$ & 16 & $\begin{array}{l}\text { Lapatinib plus } \\
\text { temozolomide }\end{array}$ & iORR $66.7 \%$ & $\begin{array}{l}\text { PFS } 2.6 \\
\text { OS } 10.9\end{array}$ \\
\hline Pyrotinib & $\begin{array}{l}\text { PERMEATE [54] } \\
\text { single-arm phase II } \\
\text { study }\end{array}$ & $\begin{array}{c}78 \\
\text { Cohort A (without } \\
\text { RT) } \\
\text { Cohort B (after RT) }\end{array}$ & $\begin{array}{l}\text { Pyrotinib plus } \\
\text { capecytabine }\end{array}$ & $\begin{array}{l}\text { iORR } 74.6 \% \\
\text { iORR } 42 \%\end{array}$ & $\begin{array}{c}\text { PFS } 11.3 \\
\text { PFS } 5.6\end{array}$ \\
\hline
\end{tabular}


Table 1. Cont.

\begin{tabular}{|c|c|c|c|c|c|}
\hline Main Agent & Type of Study & $\begin{array}{c}\text { Number of } \\
\text { Patients with } \\
\text { Brain Metastases }\end{array}$ & $\begin{array}{l}\text { Scheme of } \\
\text { Treatment }\end{array}$ & $\begin{array}{c}\text { Intracranial } \\
\text { Response Rate * }\end{array}$ & $\begin{array}{l}\text { Median } \\
\text { PFS/OS } \\
\text { (Months) }\end{array}$ \\
\hline \multirow{3}{*}{ Neratinib } & TBCRC 022 phase II [46] & Arm 1: 40 & Neratinib alone & iORR 8\% & - \\
\hline & $\begin{array}{l}\text { TBCRC } 022 \text { phase II non } \\
\text { randomized [46] }\end{array}$ & Arm 3A: 35 & $\begin{array}{l}\text { Neratinib plus } \\
\text { capecitabine } \\
\text { without previous } \\
\text { lapatinib }\end{array}$ & iORR $49 \%$ & $\begin{array}{l}\text { PFS } 5.5 \\
\text { OS } 13\end{array}$ \\
\hline & TBCRC 022 phase II [46] & Arm 3B:25 & $\begin{array}{l}\text { Neratinib plus } \\
\text { capecitabine after } \\
\text { lapatinib }\end{array}$ & iORR 33\% & $\begin{array}{l}\text { PFS } 3 \\
\text { OS } 15\end{array}$ \\
\hline \multirow{3}{*}{ Afatinib } & $\begin{array}{c}\text { LUX-Breast } 2 \text { phase II } \\
\text { trial [49] }\end{array}$ & Arm A 40 & Afatinib alone & iCBR 30\% & - \\
\hline & $\begin{array}{c}\text { LUX-Breast } 2 \text { phase II } \\
\text { trial [49] }\end{array}$ & Arm B 38 & $\begin{array}{l}\text { Afatinib plus } \\
\text { vinorelbine }\end{array}$ & iCBR $34.2 \%$ & - \\
\hline & $\begin{array}{l}\text { LUX-Breast } 2 \text { phase II } \\
\text { trial [49] }\end{array}$ & Arm C 43 & $\begin{array}{c}\text { Treatment of } \\
\text { physician choice }\end{array}$ & iCBR $41.9 \%$ & - \\
\hline Tucatinib & $\begin{array}{l}\text { HER2CLIMB phase II } \\
\text { trial [52] }\end{array}$ & 291 & $\begin{array}{l}\text { Tucatinib plus } \\
\text { trastuzumab plus } \\
\text { capecitabine }\end{array}$ & iORR $47.3 \%$ & $\begin{array}{l}\text { PFS } 9.9 \\
\text { OS } 21.6\end{array}$ \\
\hline Epertinib & $\begin{array}{c}\text { Macpherson } 2019 \text { phase } \\
\text { I/II trial [55] }\end{array}$ & $\begin{array}{c}45 / 5 \\
\text { Arm A } \\
\text { Arm B } \\
\text { Arm C }\end{array}$ & $\begin{array}{l}\text { Epertinib plus } \\
\text { trastuzumab- } \\
\text { Trastuzumab plus } \\
\text { vinorelbine- } \\
\text { Trastuzumab plus } \\
\text { capecitabine }\end{array}$ & $\begin{array}{l}\text { iORR } 67 \% \\
\text { iORR 0\% } \\
\text { iORR } 50 \%\end{array}$ & - \\
\hline Bevacizumab & $\begin{array}{c}\text { Lin } 2013 \text { phase II trial } \\
\text { [57] }\end{array}$ & 38 & $\begin{array}{c}\text { Bevacizumab plus } \\
\text { carboplatin }+/- \\
\text { trastuzumab }\end{array}$ & iORR 63\% & - \\
\hline Cabozantinib & $\begin{array}{l}\text { Leone } 2020 \text { phase II trial } \\
\text { [56] }\end{array}$ & $\begin{array}{c}\text { Cohort 1: } 21 \\
\text { HER2+ } \\
\text { Cohort 2: } 7 \text { ER }+ \\
\text { HER2- } \\
\text { Cohort 3: } 8 \text { TNBC }\end{array}$ & $\begin{array}{l}\text { Cabozantinib }+/- \\
\text { trastuzumab }\end{array}$ & $\begin{array}{l}\text { iORR 5\% } \\
\text { iORR 14\% } \\
\text { iORR 0\% }\end{array}$ & - \\
\hline Everolimus & $\begin{array}{c}\text { LCCC } 1025 \text { phase II trial } \\
\text { [62] }\end{array}$ & 32 & $\begin{array}{l}\text { Everolimus plus } \\
\text { vinorelbine plus } \\
\text { trastuzumab }\end{array}$ & $\begin{array}{c}\text { iORR 4\% } \\
\text { iCBR3m. 65\% } \\
\text { iCBR6m. } 27 \%\end{array}$ & OS 12.2 \\
\hline \multirow[t]{2}{*}{ Abemaciclib } & JPBO [63] phase II trial & Cohort B & $\begin{array}{l}\text { Abemaciclib plus } \\
\text { trastuzumab }\end{array}$ & $\begin{array}{l}\text { iORR } 0 \% \\
\text { iCBR } 11 \%\end{array}$ & OS 10 \\
\hline & \multicolumn{5}{|c|}{ Luminal breast cancer brain metastases } \\
\hline \multirow[t]{2}{*}{ Abemaciclib } & JPBO [63] phase II trial & Cohort A & $\begin{array}{c}\text { Abemaciclib } \\
\text { monotherapy or } \\
\text { with endocrine } \\
\text { therapy }\end{array}$ & $\begin{array}{l}\text { iORR } 5.2 \% \\
\text { iCBR } 24 \%\end{array}$ & OS 12.5 \\
\hline & \multicolumn{5}{|c|}{ Triple-negative breast cancer brain metastases } \\
\hline PARP & $\begin{array}{c}\text { TBCRC } 018 \text { phase II trial } \\
\text { [64] }\end{array}$ & 34 & $\begin{array}{l}\text { Iniparib plus } \\
\text { irinotecan }\end{array}$ & $\begin{array}{l}\text { iORR } 12 \% \\
\text { iCBR } 27 \%\end{array}$ & $\begin{array}{l}\text { TTP } 2.1 \\
\text { OS } 7.8\end{array}$ \\
\hline
\end{tabular}


Table 1. Cont.

\begin{tabular}{|c|c|c|c|c|c|}
\hline Main Agent & Type of Study & $\begin{array}{c}\text { Number of } \\
\text { Patients with } \\
\text { Brain Metastases }\end{array}$ & $\begin{array}{l}\text { Scheme of } \\
\text { Treatment }\end{array}$ & $\begin{array}{c}\text { Intracranial } \\
\text { Response Rate * }\end{array}$ & $\begin{array}{l}\text { Median } \\
\text { PFS/OS } \\
\text { (Months) }\end{array}$ \\
\hline Ang1005 & Kumthecar 2020 [66] & 72 & ANG1005 alone & $\begin{array}{l}\text { iORR 8\% } \\
\text { iCBR 77\% }\end{array}$ & OS 8 \\
\hline Eribulin & Adamo 2019 [68] & 118 & Eribulin mesylate & iORR $16 \%$ & $\begin{array}{l}\text { PFS } 5.5 \\
\text { OS } 31.8\end{array}$ \\
\hline $\begin{array}{l}\text { Sacituzumab } \\
\text { govitecan }\end{array}$ & $\begin{array}{c}\text { ASCENT phase III trial } \\
{[69]}\end{array}$ & $529 / 61$ & $\begin{array}{c}\text { Sacituzumab } \\
\text { govitecan }\end{array}$ & $\begin{array}{l}\text { iORR 3\% } \\
\text { iCBR 9.4\% }\end{array}$ & $\begin{array}{l}\text { PFS } 2.8 \\
\text { OS } 6.8\end{array}$ \\
\hline
\end{tabular}

\section{Old Cytotoxic Drugs}

Some retrospective and a few prospective studies investigated the response to various cytotoxic drugs in brain metastases from breast cancer. The ORR in patients treated with cyclophosphamide, fluorouracil, methotrexate, epirubicine (CMF, FEC), cisplatin, and etoposide was $38-59 \%$ and median OS was $7-13$ months $[73,74]$. The efficacy of capecitabine as a single agent was shown in small series of breast cancer patients with recurrent brain metastases [75-78]. In another study, the combination of capecitabine with temozolomid demonstrated the ORR of $18 \%$ in patients who recurred after WBRT [79]. The evidence of the vinorelbine efficacy in the treatment of breast cancer brain metastases is also poor. There was no response after temozolomide combined with vinorelbine in patients with brain metastases [80]. However, in a prospective study assessing the chemotherapy with cisplatin and etoposide for patients with brain metastases from breast cancer, non-small cell lung cancer or malignant melanoma, the iORR was 38\% [81].

\section{Conclusions}

For many years, patients with breast cancer and brain metastases were excluded from participation in clinical trials because it was believed that anticancer drugs could not cross the BBB. In those days, the authors of American Society of Clinical Oncology (ASCO) recommendations did not consider instituting a systemic therapy in patients whose systemic disease was not progressive at a time of brain metastasis diagnosis. No information was posted in relation to a systemic therapy after the detection of brain lesions without metastases to other organs [82]. However, ample evidence strongly suggests that some drugs can act against brain metastases, with the greatest intracranial response rate reported in the case of capecitabine, neratinib plus capecitabine, T-DXd, and tucatinib plus trastuzumab and capecitabine. Based on the new European Association of Neuro-Oncology (EANO)-European Society for Medical Oncology (ESMO) clinical practice guidelines, a systemic therapy can play an important role in the control of brain metastases from breast cancer and it should be considered for most patients with initial brain metastases, not only after an intracranial recurrence. In asymptomatic brain metastases, a systemic treatment should be considered to delay WBRT [83].

Patients with HER2-positive breast cancer and brain metastases have now several treatment options, but in patients with TNBC or hormone receptor positive brain metastases much fewer compounds can be proposed (Table 2). Improvements in the systemic therapy for TNBC and brain metastases are urgently needed because of the worst outcome in this group of patients. Based on the presented results, patients with active brain metastases should be routinely included in clinical trials of current and novel agents. 
Table 2. The most effective systemic drugs used in breast cancer patients with brain metastases (intracranial objective response rate iORR > 30\%).

\begin{tabular}{ccc}
\hline Main Agent & Scheme of the Treatment & iORR (CR + PR) \\
\hline Pyrotinib [54] & Pyrotinib plus capecitabine before WBRT & $74.6 \%$ \\
\hline Lapatinib [43] & Lapatinib plus capecitabine before WBRT & $65.9 \%$ \\
\hline T-DXd [36,37] & T-DXd & $58.3-63.9 \%$ \\
\hline Neratinib [46] & Neratinib plus capecytabine without previous lapatinib & $49 \%$ \\
\hline Tucatinib [52] & Tucatinib plus trastuzumab plus capecitabine & $47.3 \%$ \\
\hline Neratinib [46] & Netatinib plus capecytabine after previous lapatinib & $33 \%$ \\
\hline T-DM1 [26,27,37] & T-DXd & $21-44 \%$ \\
\hline Afatinib [49] & Afatinib plus vinorelbine & $34 \%$ \\
\hline
\end{tabular}

iORR - intracranial objective response rate (complete response (CR) + partial response (PR)); T-DM1-trastuzumab emtansine; T-DXd—-trastuzumab deruxtecan; WBRT-whole-brain radiation therapy.

Author Contributions: Conceptualization, A.N.; resources, A.N. and K.P.; data curation, A.N. and K.P.; project administration, K.P. and R.D.; formal analysis, A.N.; writing-original draft, A.N.; writing-review and editing, K.P., A.J.-G. and R.D.; critically revision, K.P.; supervision, A.N. All authors have read and agreed to the published version of the manuscript.

Funding: This research received no external funding.

Conflicts of Interest: A.N. has received funds from Roche (Basel, Switzerland) and Pfizer (New York, NY, USA) Companies to pay the entry fee for oncological congresses and has been involved as a consultant and expert witness in Novartis (Basel, Switzerland). K.P. is a speaker for AstraZeneca (Cambridge, UK), Roche, Pfizer, Novartis, Eli Lilly (Indianapolis, IN, USA), Gilead (Foster City, CA, USA), BMS (New York, NY, USA), Teva (Jerusalem, Israel), Egis (Singapore), and Vipharm (Ożarów Mazowiecki, Poland), has advisory roles for AstraZeneca and Gilead, and receives travel support from Pfizer and AstraZeneca. A.J.-G. has received a speaker honorarium from Novartis, Roche, Gilead, Eli Lilly, Amgen (Southern Oaks, CA, USA), and Pfizer and has been involved as a consultant in AstraZeneca, Gilead, Eli Lilly, and Pfizer. R.D. has received a speaker honorarium from Roche, Pfizer, Novartis, AstraZeneca, and Exact Sciences (Madison, WI, USA) and has been involved as a consultant and expert witness in Gilead, AstraZeneca, Novartis, and Eli Lilly.

$\begin{array}{ll}\text { Abbreviations } \\ \text { BBB } & \text { blood-brain barrier } \\ \text { BTB } & \text { blood-tumor barrier } \\ \text { CDK } & \text { cycline-dependent kinase } \\ \text { CI } & \text { confidence interval } \\ \text { CNS } & \text { central nervous system } \\ \text { CR } & \text { complete response } \\ \text { ER } & \text { estrogen receptor } \\ \text { HER2 } & \text { human epidermal growth factor receptor } 2 \\ \text { HR } & \text { hazard ratio } \\ \text { iCBR } & \text { intracranial clinical benefit rate } \\ \text { iORR } & \text { intracranial objective response rate } \\ \text { OS } & \text { overall survival } \\ \text { PARP } & \text { poly (ADP-ribose) polymerase } \\ \text { PFS } & \text { progression-free survival } \\ \text { PI3K } & \text { phosphoinositide 3-kinase } \\ \text { PR } & \text { partial response }\end{array}$




$\begin{array}{ll}\text { RECIST 1.1 } & \begin{array}{l}\text { Response Criteria in Solid Tumors } 1.1 \\ \text { stable disease } \\ \text { SD }\end{array} \\ \text { SRS } & \text { stereotactic radiosurgery } \\ \text { TKI } & \text { tyrosine kinase inhibitor } \\ \text { TNBC } & \text { triple-negative breast cancer } \\ \text { WBRT } & \text { whole-brain radiation therapy }\end{array}$

\section{References}

1. Weil, R.J.; Palmieri, D.C.; Bronder, J.L.; Stark, A.M.; Steeg, P.S. Breast cancer metastases to the central nervous system. Am. J. Pathol. 2005, 167, 913-920. [CrossRef]

2. Kim, J.S.; Kim, I.A. Evolving treatment strategies of brain metastases from breast cancer: Current status and future direction. Ther. Adv. Med. Oncol. 2020, 12, 1758835920936117. [CrossRef] [PubMed]

3. Pestalozzi, B.C.; Holmes, E.; de Azambuja, E.; Metzger-Filhi, O.; Hogge, L.; Scullion, M.; Lang, I.; Wardley, A.; Lichinitser, M.; Sanchez, R.I.; et al. CNS relapses in patients with HER2-positive early breast cancer who have and have not received adjuvant trastuzumab: A retrospective substudy of the HERA trial (BIG 1-01). Lancet Oncol. 2013, 14, 244-248. [CrossRef]

4. Raghunath, A.; Desai, K.; Ahluwalia, M.S. Current treatment options for breast cancer brain metastases. Curr. Treat. Options Oncol. 2019, 20, 19. [CrossRef]

5. Kennecke, H.; Yerushalmi, R.; Woods, R.; Cheang, M.C.; Voduc, D.; Speers, C.H.; Nielsen, T.O.; Gelmon, K. Metastatic behavior of breast cancer subtypes. J. Clin. Oncol. 2010, 28, 3271-3277. [CrossRef]

6. $\quad$ Lin, N.U.; Vanderplas, A.; Hughes, M.E.; Theriault, R.L.; Edge, S.B.; Wong, Y.N.; Blayney, D.W.; Niland, J.C.; Winer, E.P.; Weeks, J.C. Clinicopathologic features, patterns of recurrence, and survival among women with triple-negative breast cancer in the National Comprehensive Cancer Network. Cancer 2012, 118, 5463-5472. [CrossRef]

7. Gobbini, E.; Ezzalfani, M.; Dieras, V.; Bachelot, T.; Brain, E.; Debled, M.; Jacot, W.; Mouret-Reynier, M.A.; Goncalves, A.; Dalenc, F.; et al. Time trends of overall survival among metastatic breast cancer patients in real-life ESME cohort. Eur. J. Cancer 2018, 96, 17-24. [CrossRef]

8. Darlix, A.; Louvel, G.; Fraisse, J.; Jacot, W.; Brain, E.; Debled, M.; Mouret-Reynier, M.A.; Goncalves, A.; Dalenc, F.; Delaloge, S.; et al. Impact of breast cancer molecular subtypes on the incidence, kinetics and prognosis of central nervous system metastases in a large multicenter real-life cohort. Br. J. Cancer 2019, 121, 991-1000. [CrossRef]

9. Bailleux, C.; Eberst, L.; Bachelot, T. Treatment for breast cancer brain metastases. Br. J. Cancer 2021, 124, 142-155. [CrossRef]

10. Zhang, C.; Yu, D. Advances in decoding breast cancer brain metastasis. Cancer Metastasis Rev. 2016, 35, 677-684. [CrossRef]

11. Costa, R.; Gill, N.; Rademaker, A.W.; Carneiro, B.A.; Chae, Y.K.; Kumthekar, P.; Gradishar, W.J.; Kurzrock, R.; Giles, F.J. Systematic analysis of early phase clinical studies for patients with breast cancer: Inclusion of patients with brain metastasis. Cancer Treat. Rev. 2017, 55, 10-15. [CrossRef] [PubMed]

12. Dijkers, E.C.; Oude Munnink, T.H.; Kosterink, J.G.; Brouwers, A.H.; Jager, P.L.; de Jong, J.R.; van Dongen, G.A.; Schröder, C.P.; Lub-de Hooge, M.N.; de Vries, E.G. Biodistribution of 89Zr-trastuzumab and PET imaging of HER2-positive lesions in patients with metastatic breast cancer. Clin. Pharmacol. Ther. 2010, 89, 586-592. [CrossRef] [PubMed]

13. Arvanitis, C.D.; Ferraro, G.B.; Jain, R.K. The blood-brain barrier and blood-tumor barrier in brain tumours and metastases. Nat Rev. Cancer 2020, 20, 26-41. [CrossRef] [PubMed]

14. Babak, M.V.; Zalutsky, M.R.; Balyasnikova, I.V. Heterogeneity and vascular permeability of breast cancer brain metastases. Cancer Lett. 2020, 489, 174-181. [CrossRef]

15. Niwińska, A.; Murawska, M.; Pogoda, K. Breast cancer subtypes and response to systemic treatment after whole-brain radiotherapy in patients with brain metastases. Cancer 2010, 116, 4238-4247. [CrossRef]

16. Niwinska, A.; Pogoda, K.; Murawska, M.; Niwinski, P. Factors influencing survival in patients with breast cancer and single or solitary brain metastasis. Eur. J. Surg. Oncol. 2011, 37, 635-642. [CrossRef]

17. Niwinska, A. Brain metastases as site of first and isolated recurrence of breast cancer: The role of systemic therapy after local treatment. Clin. Exp. Metastasis 2016, 33, 677-685. [CrossRef]

18. Schroeder, T.; Bittrich, P.; Kuhne, J.F.; Noebel, C.; Leischner, H.; Fiehler, J.; Schroeder, J.; Schoen, G.; Gellißen, S. Mapping distribution of brain metastases: Does the primary tumor matter? J. Neurooncol. 2020, 147, 229-235. [CrossRef]

19. Cardinal, T.; Pangal, D.; Strickland, B.A.; Newton, P.; Mahmoodifar, S.; Mason, J.; Craig, D.; Simon, T.; Tew, B.Y.; Yu, M.; et al. Anatomical and topographical variations in the distribution of brain metastases based on primary cancer origin and molecular subtypes: A systematic review. Neurooncol. Adv. 2021, 4, vdab170. [CrossRef]

20. Erickson, A.W.; Ghodrati, F.; Habbous, S.; Jerzak, K.J.; Sahgal, A.; Ahluwalia, M.S.; Das, S. HER2-targeted therapy prolongs survival in patients with HER2-positive breast cancer and intracranial metastatic disease: A systematic review and meta-analysis. Neurooncol. Adv. 2020, 2, vdaa136. [CrossRef]

21. Swain, S.M.; Baselga, J.; Kim, S.B.; Ro, J.; Semiglazov, V.; Campone, M.; Ciruelos, E.; Ferrero, J.M.; Schneeweiss, A.; Heeson, S.; et al. Pertuzumab, trastuzumab, and docetaxel in HER2-positive metastatic breast cancer. N. Engl. J. Med. 2015, 19, 724-734. [CrossRef] 
22. Swain, S.M.; Baselga, J.; Miles, D.; Im, Y.H.; Quah, C.; Lee, L.F.; Cortés, J. Incidence of central nervous system metastases in patients with HER2-positive metastatic breast cancer treated with pertuzumab, trastuzumab, and docetaxel: Results from the randomized phase III study CLEOPATRA. Ann. Oncol. 2014, 25, 1116-1121. [CrossRef] [PubMed]

23. Lin, N.U.; Pegram, M.; Sahebjam, S.; Ibrahim, N.; Fung, A.; Cheng, A.; Nicholas, A.; Kirschbrown, W.; Kumthekar, P. Pertuzumab plus high dose trastuzumab in patients with progressive brain metastases and HER2-positive metastatic breast cancer: Primary analysis of a phase II study. J. Clin. Oncol. 2021, 39, 2667-2675. [CrossRef] [PubMed]

24. Leone, J.P.; Lin, N.U. Systemic therapy of central nervous system metastases of breast cancer. Curr. Oncol. Rep. 2019, 21, 49. [CrossRef] [PubMed]

25. Lin, N.U.; Kumthekar, P.; Sahebjam, S.; Ibrahim, N.; Fung, A.; Cheng, A.; Nicholas, A.; Wang, B.; Pegram, M. Pertuzumab (P) plus high-dose trastuzumab $(\mathrm{H})$ for the treatment of central nervous system (CNS) progression after radiotherapy (RT) in patients (pts) with HER2-positive metastatic breast cancer (MBC): Primary efficacy analysis results from the phase II PATRICIA study. Cancer Res. 2020, 80, P1-18-03. [CrossRef]

26. Bartsch, R.; Berghoff, A.S.; Vogl, U.; Rudas, M.; Bergen, E.; Dubsky, P.; Dieckmann, K.; Pinker, K.; Bago-Horvath, Z.; Galid, A.; et al. Activity of T-DM1 in HER2-positive breast cancer brain metastases. Clin. Exp. Met. 2015, 32, 729-737. [CrossRef]

27. Jacot, W.; Pons, E.; Frenel, J.S.; Guiu, S.; Levy, C.; Heudel, P.E.; Bachelot, T.; D’Hondt, V.; Darlix, A.; Firmin, N.; et al. Efficacy and safety of trastuzumab emtansine (T-DM1) in patients with HER2-positive breast cancer with brain metastases. Breast Cancer Res. Treat. 2016, 157, 307-318. [CrossRef]

28. Fabi, A.; Alesini, D.; Valle, E.; Moscetti, L.; Caputo, R.; Caruso, M.; Carbognin, L.; Ciccarese, M.; La Verde, N.; Arpino, G.; et al. T-DM1 and brain metastases: Clinical outcome in HER2-positive metastatic breast cancer. Breast 2018, 41, 137-143. [CrossRef]

29. Montemurro, F.; Ellis, P.; Anton, A.; Wuerstlein, R.; Delaloge, S.; Bonneterre, J.; Quenel-Tueux, N.; Linn, S.C.; Irahara, N.; Donica, M.; et al. Safety of trastuzumab emtansine (T-DM1) in patients with HER2-positive advanced breast cancer: Primary results from the KAMILLA study cohort 1. Eur. J. Cancer 2019, 109, 92-102. [CrossRef]

30. Montemurro, F.; Delaloge, S.; Barrios, C.H.; Wuerstlein, R.; Anton, A.; Brain, E.; Hatschek, T.; Kelly, C.M.; Peña-Murillo, C.; Yilmaz, M.; et al. Trastuzumab emtansine (T-DM1) in patients with HER2-positivemetastatic breast cancer and brain metastases: Exploratory final analysis of cohort 1 from KAMILLA, a single-arm phase IIIb clinical trials. Ann. Oncol. 2020, 10, 1350-1358. [CrossRef]

31. Verma, S.; Miles, D.; Gianni, L.; Krop, I.E.; Welslau, M.; Baselga, J.; Pegram, M.; Oh, D.Y.; Diéras, V.; Guardino, E.; et al. Trastuzumab emtansine for HER2-positive advanced breast cancer. N. Engl. J. Med. 2012, 367, 1783-1791. [CrossRef] [PubMed]

32. Dieras, V.; Miles, D.; Verma, S.; Pegram, M.; Welslau, M.; Baselga, J.; Krop, I.E.; Blackwell, K.; Hoersch, S.; Xu, J.; et al. Trastuzumab emtansine versus capecitabine plus lapatinib in patients with previously treated HER2-positive advanced breast cancer (EMILIA): A descriptive analysis of final overall survival results from a randomized, open-labeled, phase 3 trial. Lancet Oncol. 2017, 18, 732-742. [CrossRef]

33. Krop, I.E.; Lin, N.U.; Blackwell, K.; Guardino, E.; Huober, J.; Lu, M.; Miles, D.; Samant, M.; Welslau, M.; Diéras, V. Trastuzumab emtansine (T-DM1) versus lapatinib plus capecitabine in patients with HER2-positive metastatic breast cancer and central nervous system metastases: A retrospective, exploratory analysis in EMILIA. Ann. Oncol. 2015, 26, 113-119. [CrossRef]

34. Keam, S.J. Trastuzumab Deruxtecan: First Approval. Drugs 2020, 80, 501-508. [CrossRef] [PubMed]

35. Modi, S.; Saura, C.; Yamashita, T.; Park, Y.H.; Kim, S.B.; Tamura, K.; Andre, F.; Iwata, H.; Ito, Y.; Tsurutani, J.; et al. Trastuzumab deruxtecan in previously treated HER2-positive breast cancer. N. Engl. J. Med. 2020, 382, 610-621. [CrossRef]

36. Jerusalem, G.; Park, Y.H.; Yamashita, T.; Hurvitz, S.A.; Chen, S.; Cathcart, J.; Lee, C.; Perrin, C. CNS metastases in HER2-positive metastatic breast cancer treated with trastuzumab deruxtecan: DESTINY-Breast 01 subgroup analyses. Ann. Oncol. 2020, 31 (Suppl. S2), S63-S64. [CrossRef]

37. Hurvitz, S.; Kim, S.B.; Chung, W.P.; Im, S.A.; Park, Y.H.; Hegg, R.; Kim, M.H.; Tseng, L.M.; Petry, V.; Chung, C.F.; et al. Trastuzumab Deruxtecan (T-DXd; DS-8201a) vs. Trastuzumab Emtansine (T-DM1) in Patients (pts) with HER2+ Metastatic Breast Cancer (mBC): Subgroup Analyses from the Randomized Phase 3 Study DESTINY-Breast 03. In Proceedings of the San Antonio Breast Cancer Symposium 2021, San Antonio, TX, USA, 7-10 December 2021; Abstract GS3-01; Seagen Inc.: Bothell, WA, USA.

38. Batista, M.V.; Cortez, P.; Ruiz, M.; Cejalvo, J.M.; de la Haba, J.; Garrigós, L.; Racca, F.; Servitja, S.; Blanch, S.; Teruel, I.; et al. Trastuzumab Deruxtecan (T-DXd; DS-8201a) in Patients with HER2-Positive or HER2-low-Expressing Advanced Breast Cancer and Central Nervous System Involvement: Preliminary Results from the DEBBRAH Phase II study. In Proceedings of the San Antonio Breast Cancer Symposium 2021, San Antonio, TX, USA, 7-10 December 2021; Abstract PD4-06; Seagen Inc.: Bothell, WA, USA.

39. Lin, N.U.; Diéras, V.; Paul, D.; Lossignol, D.; Christodoulou, C.; Stemmler, H.J.; Roché, H.; Liu, M.C.; Greil, R.; Ciruelos, E.; et al. Multicenter phase II study of lapatinib in patients with brain metastases from HER2-positive breast cancer. Clin. Cancer Res. 2009, 15, 1452-1459. [CrossRef]

40. Cetin, B.; Benekli, M.; Oksuzoglu, B.; Koral, L.; Ulas, A.; Dane, F.; Turker, I.; Kaplan, M.A.; Koca, D.; Boruban, C.; et al. Lapatinib plus capecitabine for brain metastases in patients with human epidermal growth factor receptor 2-positive advanced breast cancer: A review of the Anatolian Society of Medical Oncology (ASMO) experience. Oncologie 2012, 35, 740-745. [CrossRef] [PubMed]

41. Sutherland, S.; Ashley, S.; Miles, D.; Chan, S.; Wardley, A.; Davidson, N.; Bhatti, R.; Shehata, M.; Nouras, H.; Camburn, T.; et al. Treatment of HER2-positive metastatic breast cancer with lapatinib and capecitabine in the lapatinib expanded access programme, including efficacy in brain metastases—the UK experience. Br. J. Cancer 2010, 102, 995-1002. [CrossRef] [PubMed] 
42. Petrelli, F.; Ghidini, M.; Lonati, V.; Tomasello, G.; Borgonovo, K.; Ghilardi, M.; Cabiddu, M.; Barni, S. The efficacy of lapatinib and capecitabine in HER2-positive breast cancer with brain metastases: A systematic review and pooled analysis. Eur. J. Cancer 2017, 84, 141-148. [CrossRef]

43. Bachelot, T.; Romieu, G.; Campone, M.; Diéras, V.; Cropet, C.; Dalenc, F.; Jimenez, M.; Le Rhun, E.; Pierga, J.Y.; Gonçalves, A.; et al. Lapatinib plus capecitabine in patients with previously untreated brain metastases from HER2-positive metastatic breast cancer (LANDSCAPE): A single-group phase 2 study. Lancet Oncol. 2013, 14, 64-71. [CrossRef]

44. de Azambuja, E.; Zardavas, D.; Lemort, M.; Rossari, J.; Moulin, C.; Buttice, A.; D’Hondt, V.; Lebrun, F.; Lalami, Y.; Cardoso, F.; et al. Phase I trial combining temozolomide plus lapatinib for the treatment of brain metastases in patients with HER2-positive metastatic breast cancer: The LAPTEM trial. Ann. Oncol. 2013, 24, 2985-2989. [CrossRef]

45. Lin, N.U.; Eierman, W.; Greil, R.; Campone, M.; Kaufman, B.; Steplewski, K.; Lane, S.R.; Zembryki, D.; Rubin, S.D.; Winer, E.P. Randomized phase II study of lapatinib plus capecytabine or lapatinib plus topotecan for patients with HER2-positive breast cancer brain metastases. J. Neurooncol. 2011, 105, 613-620. [CrossRef] [PubMed]

46. Freedman, R.A.; Gelman, R.S.; Anders, C.K.; Melisko, M.E.; Parsons, H.A.; Cropp, A.M.; Silvestri, K.; Cotter, C.M.; Componeschi, K.P.; Marte, J.M.; et al. TBCRC 022: A phase II trial of neratinib and capecitabine for patients with human epidermal growth factor receptor 2-positive breast cancer and brain metastases. J. Clin. Oncol. 2019, 37, 1081-1089. [CrossRef] [PubMed]

47. Saura, C.; Oliveira, M.; Feng, Y.H.; Dai, M.S.; Chen, S.W.; Hurvitz, S.A.; Kim, S.B.; Moy, B.; Delaloge, S.; Gradishar, W.; et al. Neratinib + capecytabine versus lapatinib + capecytabine in HER2+ metastatic breast cancer previously treated with $\geq 2$ HER2-directed regimens: Phase III NALA trial. J. Clin. Oncol. 2020, 38, 3138-3149. [CrossRef] [PubMed]

48. Awada, A.; Colomer, R.; Inoue, K.; Bondarenko, I.; Badwe, R.A.; Demetriou, G.; Lee, S.C.; Mehta, A.O.; Kim, S.B.; Bachelot, T.; et al. Neratinib Plus Paclitaxel vs. Trastuzumab Plus Paclitaxel in Previously Untreated Metastatic ERBB2-Positive Breast Cancer: The NEfERT-T Randomized Clinical Trial. JAMA Oncol. 2016, 2, 1557-1564. [CrossRef] [PubMed]

49. Cortes, J.; Dieras, V.; Ro, J.; Barriere, J.; Bachelot, T.; Hurvitz, S.; Le Rhun, E.; Espié, M.; Kim, S.B.; Schneeweiss, A.; et al. Afatinib alone or afatinib plus vinorelbine versus investigator's choice of treatment for HER2-positive breast cancer with progressive brain metastases after trastuzumab, lapatinib, or both (LUX-Breast 3): A randomized, open-label, multicentre, phase 2 trial. Lancet Oncol. 2015, 16, 1700-1710. [CrossRef]

50. Murthy, R.; Borges, V.F.; Conlin, A.; Chaves, J.; Chamberlain, M.; Gray, T.; Vo, A.; Hamilton, E. Tucatinib with capectabine and trastuzumab in advanced HER2-positive metastatic breast cancer with and without brain metastases: A non-randomized, open-label, phase 1b study. Lancet Oncol. 2018, 19, 880-888. [CrossRef]

51. Murthy, R.K.; Loi, S.; Okines, A.; Paplomata, E.; Hamilton, E.; Hurvitz, S.A.; Lin, N.U.; Borges, V.; Abramson, V.; Anders, C.; et al. Tucatinib, trastuzumab, and capecitabine for HER2-positive metastatic breast cancer. N. Engl. J. Med. 2020, 13, 597-609. [CrossRef]

52. Lin, U.N.; Murthy, R.K.; Abramson, V.; Anders, C.; Bachelot, T.; Bedard, P.; Borges, V.; Cameron, D.; Carey, L.; Jo Chien, A.; et al. Updated Results of Tucatinib vs. Placebo Added to Trastuzumab and Capecitabine for Patients with Previously Treated HER2+ Metastatic Breast Cancer with Brain Metastases (HER2CLIMB). In Proceedings of the San Antonio Breast Cancer Symposium 2021, San Antonio, TX, USA, 7-10 December 2021; Abstract PD4-04; Seagen Inc.: Bothell, WA, USA.

53. Xu, B.; Yan, M.; Ma, F.; Hu, X.; Feng, J.; Ouyang, Q.; Tong, Z.; Li, H.; Zhang, Q.; Sun, T.; et al. Updated Overall Survival (OS) Results from the Phase III PHOEBE Trial of Pyrotinib Versus Lapatinib in Combination with Capecitabine in Patients with HER2-Positive Metastatic Breast Cancer. In Proceedings of the San Antonio Breast Cancer Symposium 2021, San Antonio, TX, USA, 7-10 December 2021; Abstract GS3-02; Seagen Inc.: Bothell, WA, USA.

54. Yan, M.; Ouyang, O.; Sun, T.; Niu, L.; Yang, J.; Li, L.; Song, Y.; Hao, C.; Chen, Z. Pyrotinib plus capecitabine for HER2-positive metastatic breast cancer with brain metastases (PERMEATE): A multicenter, single arm, phase II study. J. Clin. Oncol. 2021, 39 (Suppl. 15), 1037. [CrossRef]

55. Macpherson, I.R.; Spiliopoulou, P.; Rafii, S.; Saggese, M.; Baird, R.D.; Garcia-Corbacho, J.; Italiano, A.; Bonneterre, J.; Campone, M.; Cresti, N.; et al. A phase I/II study of epertinib plus trastuzumab with or without chemotherapy in patients with HER2-positive metastatic breast cancer. Breast Cancer Res. 2019, 22, 1. [CrossRef] [PubMed]

56. Leone, J.P.; Duda, D.G.; Hu, J.; Barry, W.T.; Trippa, L.; Gerstner, E.R.; Jain, R.K.; Tan, S.; Lawler, E.; Winer, E.P.; et al. A phase II study of cabozantinib alone or in combination with trastuzumab in breast cancer patients with brain metastases. Breast Cancer Res. Treat. 2019, 179, 113-123. [CrossRef] [PubMed]

57. Lin, N.U.; Gelman, R.S.; Younger, J.W.; Sohl, J.; Freedman, R.A.; Gregory Sorensen, A.; Bullitt, E.; Harris, G.J.; Morganstern, D.; Schneider, B.P.; et al. Phase II trial of carboplatin (C) and bevacizumab (BEV) in patients (PTS) with breast cancer brain metastases (BCBM). J. Clin. Oncol. 2013, 31 (Suppl. S15), 513. [CrossRef]

58. Lu, Y.S.; Chen, T.W.; Lin, C.H.; Yeh, D.C.; Tseng, L.M.; Wu, P.F.; Rau, K.M.; Chen, B.B.; Chao, T.C.; Huang, S.M.; et al. Bevacizumab preconditioning followed by etoposide and cisplatin is highly effective in treating brain metastases of breast cancer progressing from whole-brain radiotherapy. Clin. Cancer Res. 2015, 21, 1851-1858. [CrossRef] 
59. Pors, H.; von Eyben, F.E.; Sorensen, O.S.; Larsen, M. Longterm remission of multiple brain metastases with tamoxifen. J. Neurooncol. 1991, 10, 173-177. [CrossRef]

60. Madhup, R.; Kirti, S.; Bhatt, M.L.; Srivastava, P.K.; Srivastava, M.; Kumar, S. Letrozol for brain and scalp metastases from breast cancers-A case report. Breast 2006, 15, 440-442. [CrossRef]

61. Rusz, O.; Kószó, R.; Dobi, Á.; Csenki, M.; Valicsek, E.; Nikolényi, A.; Uhercsák, G.; Cserháti, A.; Kahán, Z. Clinical benefit of fulvestrant monotherapy in the multimodal treatment of hormone receptor and HER2 positive advanced breast cancer: A case series. Onco Targets Ther. 2018, 11, 5459-5463. [CrossRef]

62. Van Swearingen, A.E.D.; Siegel, M.B.; Deal, A.M.; Sambade, M.J.; Hoyle, A.; Hayes, D.N.; Jo, H.; Little, P.; Dees, E.C.; Muss, H.; et al. A phase II study of everolimus, trastuzumab, and vinorelbine to treat progressive HER2-positive breast cancer brain metastases. Breast Cancer Res. Treat. 2018, 171, 637-648. [CrossRef]

63. Tolaney, S.M.; Sahebjam, S.; Le Rhun, E.; Bachelot, T.; Kabos, P.; Awada, A.; Yardley, D.; Chan, A.; Conte, P.; Diéras, V.; et al. A phase II study of abemacyklib in patients with brain metastases secondary to hormone receptor-positive breast cancer. Clin. Cancer Res. 2020, 26, 5310-5319. [CrossRef]

64. Anders, C.; Deal, A.M.; Abramson, V.; Liu, M.C.; Storniolo, A.M.; Carpenter, J.T.; Puhalla, S.; Nanda, R.; Melhem-Bertrandt, A.; Lin, N.U.; et al. TBCRC 018: Phase II study of iniparib in combination with irinotecan to treat progressive triple negative breast cancer brain metastases. Breast Cancer Res. Treat. 2014, 146, 557-566. [CrossRef]

65. Litton, J.K.; Rugo, H.S.; Ettl, J.; Hurvitz, S.A.; Gonçalves, A.; Lee, K.H.; Fehrenbacher, L.; Yerushalmi, R.; Mina, L.A.; Martin, M.; et al. Talazoparib in patients with advanced breast cancer and germline BRCA mutation. N. Engl. J. Med. 2018, 379, 753-763. [CrossRef] [PubMed]

66. Kumthekar, P.; Tang, S.C.; Brenner, A.J.; Kesari, S.; Piccioni, D.E.; Anders, C.; Carrillo, J.; Chalasani, P.; Kabos, P.; Puhalla, S.; et al. ANG1005, a brain-penetrating peptide-drug conjugate, shows activity in patients with breast cancer with leptomeningeal carcinomatosis and recurrent brain metastases. Clin. Cancer Res. 2020, 26, 2789-2799. [CrossRef] [PubMed]

67. Tripathy, D.; Tolaney, S.M.; Seidman, A.D.; Anders, C.K.; Ibrahim, N.; Rugo, H.S.; Twelves, C.; Dieras, V.; Müller, V.; Tagliaferri, M.; et al. ATTAIN: Phase III study of etirinotecan pegol versus treatment of physician's choice in patients with metastatic breast cancer and brain metastases. Future Oncol. 2019, 15, 2211-2225. [CrossRef] [PubMed]

68. Adamo, V.; Ricciardi, G.R.R.; Giuffrida, D.; Scandurra, G.; Russo, A.; Blasi, L.; Spadaro, P.; Iacono, C.; Soto Parra, H.J.; Savarino, A.; et al. Eribulin mesylate use as third-line therapy in patients with metastatic breast cancer (VESPRY): A prospective, multicenter, observational study. Ther. Adv. Med. Oncol. 2019, 11, 1758835919895755. [CrossRef] [PubMed]

69. Diéras, V.; Weaver, R.; Tolaney, S.M.; Bardia, A.; Punie, K.; Brufsky, A.; Rugo, H.S.; Kalinsky, K.; Traina, T.; Klein, L.; et al. Subgroup analysis of patients with brain metastases from the phase III ASCENT study of sacituzumab govitecan versus chemotherapy in metastatic triple-negative breast cancer. Cancer Res. 2021, 81 (Suppl. S4), PD13-07. [CrossRef]

70. Schmid, P.; Adams, S.; Rugo, H.S.; Schneeweiss, A.; Barrios, C.H.; Iwata, H.; Diéras, V.; Hegg, R.; Im, S.A.; Shaw Wright, G.; et al. Atezolizumab and nab-paclitaxel in advanced triple-negative breast cancer. N. Engl. J. Med. 2018, 379, 2108-2121. [CrossRef]

71. Du, W.; Sirbu, C.; Lucas, B.D., Jr.; Jubelirer, S.J.; Khalid, A.; Mei, L. A retrospective study of brain metastases from solid malignancies: The effect of immune checkpoint inhibitors. Front. Oncol. 2021, 11, 667847. [CrossRef]

72. Ahmed, K.A.; Kim, Y.; Arrington, J.A.; Kim, S.; De Jesus, M.; Soyano, A.E.; Armaghani, A.J.; Costa, R.L.B.; Khong, H.T.; Loftus, L.S.; et al. Nivolumab and Stereotactic Radiosurgery for Patients with Breast Cancer Brain Metastases: A Nonrandomized, Open-Label Phase 1b Study. Adv. Radiat. Oncol. 2021, 6, 100798. [CrossRef]

73. Boogerd, W.; Dalesio, O.; Bais, E.M.; van der Sande, J.J. Response of brain metastases from breast cancer to systemic therapy. Cancer 1992, 69, 972-980. [CrossRef]

74. Cocconi, G.; Lottici, R.; Bisagni, G.; Bacchi, M.; Tonato, M.; Passalacqua, R.; Boni, C.; Belsanti, V.; Bassi, P. Combination therapy with platinum and etoposide of brain metastases from breast carcinoma. Cancer Investig. 1990, 8, 327-334. [CrossRef]

75. Fabi, A.; Vidiri, A.; Ferretti, G.; Felici, A.; Papaldo, P.; Carlini, P.; Mirri, A.; Nuzzo, C.; Cognetti, F. Dramatic regression of multiple brain metastases from breast cancer with capecitabine: Another arrow at the bow? Cancer Investig. 2006, 24, 466-468. [CrossRef] [PubMed]

76. Hikino, H.; Yamada, T.; Johbara, K.; Obayashi, N.; Ozaki, N. Potential role of chemo-radiation with oral capecitabine in a breast cancer patient with central nervous system relapse. Breast 2006, 15, 97-99. [CrossRef] [PubMed]

77. Wang, M.L.; Yung, W.K.; Royce, M.E.; Schomer, D.F.; Theriault, R.L. Capecitabine for 5-fluorouracil-resistant brain metastases from breast cancer. Am. J. Clin. Oncol. 2001, 24, 421-424. [CrossRef] [PubMed]

78. Ekenel, M.; Hormigo, A.M.; Peak, S.; Deangelis, L.M.; Abrey, L.E. Capecitabine therapy of central nervous system metastases from breast cancer. J. Neurooncol. 2007, 85, 223-227. [CrossRef]

79. Rivera, E.; Meyers, C.; Groves, M.; Valero, V.; Francis, D.; Arun, B.; Broglio, K.; Yin, G.; Hortobagyi, G.N.; Buchholz, T. Phase I study of capecitabine in combination with temozolomide in the treatment of patients with brain metastases from breast carcinoma. Cancer 2006, 107, 1348-1354. [CrossRef]

80. Omuro, A.M.; Raizer, J.J.; Demopoulos, A.; Malkin, M.G.; Abrey, L.E. Vinorelbine combined with a protracted course of temozolomide for recurrent brain metastases: A phase I trial. J. Neurooncol. 2006, 78, 277-280. [CrossRef]

81. Franciosi, V.; Cocconi, G.; Michiara, M.; Di Costanzo, F.; Fosser, V.; Tonato, M.; Carlini, P.; Boni, C.; Di Sarra, S. Front-line chemotherapy with cisplatin and etoposide for patients with brain metastases from breast carcinoma, nonsmall cell lung carcinoma, or malignant melanoma: A prospective study. Cancer 1999, 85, 1599-1605. [CrossRef] 
82. Ramakrishna, N.; Temin, S.; Chandarlapaty, S.; Crews, J.R.; Davidson, N.E.; Esteva, F.J.; Giordano, S.H.; Kirshner, J.J.; Krop, I.E.; Levinson, J.; et al. Recommendations on disease management for patients with advanced human epidermal growth factor receptor 2-positive breast cancer and brain metastases: ASCO Clinical Practice Guideline Update. J. Clin. Oncol. 2018, 36, 2804-2807. [CrossRef]

83. Le Rhun, E.; Guckenberger, M.; Smits, M.; Dummer, R.; Bachelot, T.; Sahm, F.; Galldiks, N.; de Azambuja, E.; Berghoff, A.S.; Metellus, P.; et al. EANO-ESMO Clinical Practice Giudelines for diagnosis, treatment and follow-up of patients with brain metastasis from solid tumours. Ann. Oncol. 2021, 32, 1332-1347. [CrossRef] 